\title{
Pengaruh Kualitas Lingkungan Pendidikan Terhadap Prestasi Belajar Taruna Akpelni Semarang Tahun 2017
}

\author{
Soemadi ${ }^{1)}$, Cahya Fajar Budi Hartanto ${ }^{2)}$, Astri Kustina Dewi ${ }^{3)}$, Dalmadi'), Ridwan ${ }^{5)}$, Retno \\ Indriyati ${ }^{6}$ \\ 1), 2), 3), 6) Program Studi Nautika Akademi Pelayaran Niaga Indonesia \\ e-mail : ${ }^{1)}$ soemadi idameos@yahoo.com, ${ }^{2)}$ fajar@akpelni.ac.id, ${ }^{3)}$ astri@akpelni.ac.id, \\ ${ }^{6}$ retno@akpelni.ac.id \\ 4) Program Studi teknika Akademi Pelayaran Niaga Indonesia \\ e-mail : dalmadi@akpelni.ac.id \\ 5)Program Studi Ketatalaksanaan Pelayaran Niaga dan Kepelabuhanan Akademi Pelayaran Niaga Indonesia \\ e-mail : $\underline{\text { ridwan@akpelni.ac.id }}$
}

\begin{abstract}
ABSTRAK
Soemadi, Cahya Fajar Budi Hartanto, Astri Kustina Dewi, Dalmadi, Ridwan, Retno Indriyati. Pengaruh Kualitas Lingkungan Pendidikan Terhadap Prestasi Belajar Taruna Akpelni Semarang Tahun 2017

Penelitian ini merupakan penelitian Kausal Komparatif atau Ex Post Facto dengan metode pendekatan kuantitatif yang bertujuan untuk mengetahui faktor penyebab adanya suatu akibat yang dilihat dan dirasakan yaitu prestasi belajar Taruna yang kurang baik. Hipotesis awal adalah ada pengaruh dari kualitas lingkungan pendidikan terhadap prestasi belajar. Kualitas lingkungan pendidikan yang dimaksud adalah Dosen, Kualitas Pembelajaran, Kualitas Kehidupan di Asrama, Kualitas Kedisiplinan dan Kualitas Raw Input.
\end{abstract}

Metode pengumpulan data adalah dengan metode random sampling dimana untuk Taruna digunakan sampel 251 responden, untuk Dosen ( Tetap dan Tidak tetap ) digunakan sampel 38 Responden, untuk Instruktur dan Bintar diambil sampling jenuh sebanyak 16 .

Hasil penelitian menunjukkan bahwa variabel Kualitas Dosen, Kualitas Pembelajaran, Kualitas Kehidupan di Asrama, Kualitas Kedisiplinan tidak berpengaruh secara signifikan terhadap prestasi belajar, yang berarti ini tidak masalah. Sedangkan variabel Kualitas Raw Input berpengaruh positif dan signifikan terhadap prestasi belajar.

Kata Kunci : Kualitas, Dosen, Kualitas Pembelajaran, Kehidupan di Asrama, Kedisiplinan, raw Input, Prestasi Belajar 
A. Latar Belakang

Pendidikan adalah hal yang utama dan terutama didalam kehidupan. Pada era sekarang ini. Pendidikan merupakan kebutuhan pokok bahkan mutlak bagi manusia dalam rangka merubah keadaan hidupnya menjadi lebih baik dan terarah. Pendidikan juga menjadi sarana untuk meraih cita- cita dan kesejahteraan menurut konsep pandang hidup manusia.

Pendidikan formal di sekolah sekolah merupakan satu bagian dari pendidikanmanusia meskipun terbagi dalam tingkatan tingkatan, namun pendidikan formal merupakan pendidikan Inti yang mempengaruhi proses pendidikan keseluruhan. Pendidikan formal bersifat sistematis dan konsisten berdasarkan pandangan teoridan praktek sesuai dengan kebutuhan peserta didik.Secara umum pendidikan dapat mengarahkan peserta didik terhadap peningkatan penguasaan pengetahuan kemampuan, ketrampilan, pengembangan sikap dan nilai-nilai dalam rangka pembentukan dan pengembangan diri dari peserta didik.

Akpelni selaku pelaksana pendidikan, telah memberikan pembelajaran kepada peserta didik dalam hal ini Taruna Akpelni melalui dosen atau tenaga pengajar yang kualitasnya baik.

Istilah kualitas menurut ISO 8402 dan SNI disebutkan adalah keseluruhan ciri dan karakteristik produk atau jasa yang kemampuannya dapat memuaskan kebutuhan baik yang dinyatakan secara tegas maupun tersamar

Yayasan Wiyata Dharma yang merupakan Badan

Penyelenggara Perguruan Tinggi AKPELNI telah mempersiapkan semuanya dengan baik, tidak hanya dosen atau tenaga pengajar tetapi secara umum lingkungan pendidikan secara keseluruhan telah disiapkan dengan baik.

Termasuk lingkungan pendidikan disini antara lain : Dosen, Metode pembelajaran, Kehidupan Taruna diasrama, Instruktur dan Bintar, Pembinaan karakter Taruna termasuk didalamnya kedisplinan, etika, dan estetika, serta Raw input.

Dosen adalah pendidik professional dan ilmuwan dengan tugas utama mentransformasikan, mengembangkan, dan menyebarluaskan ilmupengetahuan, tehnologi, dan seni melalui pendidikan, penelitian,dan pengabdian kepada masyarakat. (UU No 14/2005).

Sebagaimana kita ketahui bahwa dosen merupakan salah satu komponen Pendidikan yang utama dan Direktorat Jenderal Pendidikan Tinggi telah menentukan persyaratan persyaratan yang harus dipenuhi seorang dosen antara lain minimal S2 dan melaksanakan Tri Dharma Perguruan Tinggi yaitu Pendidikan, Penelitian dan Pengabdian pada masyakakat. Dosen Akpelni karena 


\begin{abstract}
berkeinginan untuk maju hampir semuanya telah mengikuti Program Pasca Sarjana sehingga ketentuan Dikti tersebut sudah terpenuhi.
\end{abstract}

Dengan di latar belakangi tanggung jawab moral bahwa penyelenggara pendidikan harus mampu mencetak anak didiknya menjadi manusia yangpandai, terampil, berbudi pekerti yang luhur, ( ber etika, ber estetika,disiplin dan bertanggung jawab), maka Pelaksana Pendidikan disini Direktur dengan para Pembantu Direktur perlu kiranya merancang dan mengatur system pembelajarannya agar hal tersebut bisa terwujud. Akademi Pelayaran Niaga Indonesia (Akpelni) Semarang ingin terus mencetak Taruna yang prestasinya baik, berbudi pekerti luhur,disiplin, menyiapkan segala sesuatunya agar proses belajar mengajardapat berjalan dengan baik, benar dan lancar, serta apa yang menjadi tanggung jawabnya dapat terlaksana dengan baik. Namun demikian, perkembangan saat ini dirasakan bahwa ternyata Akpelni dinilai kurang dapat mewujudkan Taruna yang prestasinya baik,berbudi pekerti luhur, beretika , serta disiplin . Padahal dari segi pendidik,fasilitas pembelajaran, fasilitas pendukung telah terpenuhi dengan baik dengan maksud agar Taruna dapat lebih nyaman belajar dan membangun diri. Masalah tersebut mendorong dosen Akpelni untuk melakukan penelitian terkait dengan Pengaruh Kualitas Lingkungan Pendidikan terhadap Prestasi Belajar Taruna, dimana hasil penelitiannya nanti dapat memberikan sumbangan pemikiran perbaikan kualitas Taruna untuk masa sekarang dan masa yang akan datang.

\section{B. Pengertian} kualitas, Pembelajaran, Kehidupan Taruna di asrama, Disiplin dan Raw input

\section{Pengertian Kualitas}

Kualitas menurut ISO 8402 dan SNI adalah keseluruhan karakteristik produk atau jasa yang kemampuannya dapat memuaskan kebutuhan baik yang dinyatakan secara tegas maupun tersamar. Akan tetapi banyak pakar dan organisasi yang mencoba mendefinisikan kualitas (mutu) berdasarkan sudut pandangnya masingmasing seperti yang terurai di bawahini. ${ }^{1}$ )

a. Menurut Joseph Juran, kualitas adalah kesesuaian untuk penggunaan (fitness for use), ini berarti bahwa suatu produk atau jasa hendaklah sesuai dengan apa yangdiperlukan atau diharapkan oleh pengguna.

b. Menurut Edward Deming,suatu tingkat yang dapat diprediksi dari keseragaman dan kebergantungan pada biaya rendah dan sesuai dengan pasar.

c. Welch Jr mengatakan bahwa kualitas adalah jaminan kesetiaan 
pelanggan, pertahanan terbaik melawan saingan dari luar, dan satu-satunya jalan menuju pertumbuhan. Secara umum, kualitas merupakan kondisi dinamis yang berhubungan dengan produk, jasa, manusia, proses, dan lingkungan yang memenuhi atau melebihi harapan.

Definisi di atas mempunyai kesamaan elemen-elemen seperti, kualitas meliputi usaha memenuhi atau melebihi harapan Taruna, kualitas mencakup produk jasa, manusia, proses dan lingkungan, kualitas merupakan kondisi yang selalu berubah karena yang dianggap kualitas saat ini mungkin di anggap kurang berikualitas pada masa mendatang.

Kualifikasi dosen Akpelni sudah memenuhi persyaratan baik dari Dikti maupun Dir.Jen Perhubungan Laut. Dosen memberikan pembelajaran akademis, Instruktur dan Bintar memberikan pembinaan Karakter dan kedisplinan.

\section{Pembelajaran}

Salah satu indikator yang dapat digunakan untuk menilai kualitas dosen adalah kemampuan mengajar dosen tersebut. Santrock (2007:7) menyatakan bahwa dosen memiliki strategi pengajaran yang baik dan didukung oleh metode penetapan tujuan, rancangan pengajaran, dan manajemen kelas.

Dari pernyataan tersebut pada dasarnya seorang dosen harus mempunyai dua kompetensi sekaligus, yakni menguasai materi yang akan diajarkan dan menguasai metode dan teknik mengajarkan materi kepada mahasiswa atau Taruna.

Dalam hal penguasaan materi pelajaran, dosen harus berpengetahuan, fleksibel, dan memahami materi. Secara lebih rinci, Leighbody dan Kidd (1968:21) menyebutkan sekaligus memberikan tuntunan kepada instruktur dalam hal ini adalah dosen yang mengajar kompetensi praktik.

Tuntunan tersebut dibagi menjadi empat tahapan, yaitu tahap: 1) persiapan, 2)presentasi, 3) aplikasi, dan 4) evaluasi. Komponen pengajaran sebagai dimensi proses belajar mengajar disampaikan Nana Sudjana (2005:57) setidaknya mencakup:

(1) tujuan pengajaran atau tujuan instruksional, (2) bahan pengajaran, (3) kondisi Mahasiswa / Taruna dan kegiatan belajarnya, (4) kondisi dosen dan kegiatan mengajarnya, (5) alat dan sumber belajar yang digunakan, dan (6) teknik dan cara pelaksanaan penilaian. UndangUndang Nomor 14 tahun 2005 tentang Guru dan Dosen Bab IV pasal 10 tentang kompetensi dosen , dijabarkan lebih lanjut dalam Peraturan Menteri Pendidikan Nasional Republik IndonesiaNomor 74 Tahun 2008 bab II pasal 3 tentang dosen, dan Peraturan Menteri Pendidikan Nomor 16 tahun 2007 tentang Standar Kualifikasi Akademik dan Kompetensi Dosen merumuskan bahwa ada empat kompetensi utama Dosen meliputi kompetensi pedagogik, 
kompetensi

kompetensi

kompetensi profesional yang diperoleh melalui pendidikan.

a. Kompetensi pedagogik

Kompetensi pedagogic

meliputi pemahaman terhadap

peserta didik, perancangan dan pelaksanaan pembelajaran, evaluasi hasil belajar, dan pengembangan peserta didik untuk mengaktualisasikan berbagai potensi yang dimilikinya. Selain itu kemampuan pedagogik juga ditunjukkan dalam membantu, membimbing dan memimpin peserta didik.

b. Kompetensi kepribadian yang dewasa memiliki indicator esensial: menampilkan

kemandirian dalam bertindak sebagai pendidik dan memiliki etos kerja sebagai dosen.

c. Kompetensi Profesional adalah kebulatan pengetahuan, ketrampilan, dan sikap yang diwujudkan dalam bentuk tindakan cerdas dan penuh tanggung jawab yang dimiliki seseorang yang memangku jabatan dosen sebagai profesi.

d. Kompetensi sosial adalah kemampuan dosen dalam berkomunikasi dan berinteraksi secara efektif dengan lingkungan sekolah maupun diluar lingkungan sekolah Disamping itu seorang dosen harus melaksanakan Tri Dharma Perguruan Tinggi yang terdiri dari Pendidikan, Penelitian dan Pengabdian pada Masyarakat

Instruktur dan Bintar melaksanakan pembinaan karakter dibawah pengawasan PD III
Karakter adalah tabiat, watak, sifat2 kejiwaan atau budi pekerti yang tumbuh dan tercermin didalam sikap atau tingkah laku seseorang yang kemudian akan membedakan orang tersebut dengan orang lain ${ }^{2}$ )

Pada dasarnya karakter seseorang tidak bisa dirubah karena, karena pembawaan manusia sejak lahir. Tetapi karakter bisa diarahkan dibina kepada hal hal yang baik, Dengan cara dibiasakan, diberi contoh tauladan yang baik, artinya sesuai dengan norma norma kehidupan manusia dimasyarakat. Norma adalah tuntutan etis dari nurani manusia yaitu apa yang boleh dilakukan dan apa yang tidak boleh dilakukan.

\section{Kehidupan Taruna di asrama.}

Dari pengamatan dan wawancaca kehidupan Taruna di asrama adalah kehidupan dalam komunitas yang bisa dikatakan homogin, artinya mereka seusia atau sebaya,dengan kebutuhan yang sama, dan dalam kesehariannya mereka hidup dalam kondisi yang sama

Tetapi pada sisi lain sesungguhnya mereka sangat heterogen ditinjau dari culture dan sosial karena mereka datang dari pelbagai daerah, dengan latar belakang sosial ekonomi, budaya, kebiasaan dan perilaku yang berbeda. Pendidikan orang tua, dan sekolah asal mereka juga berbeda, kemudian datang diasrama Akpelni, mereka dipaksa oleh aturan untuk menjadi homogen.Dalam kondisi demikian,secara psikologis ada pertentangan pada diri yang menimbulkan dampak depressi 
rasa ketidak senangan pada ruang kehidupan demikian.Taruna diharuskan mengikuti peraturan selama 24 jam penuh, tidak hanya dikampus namun juga peraturan asrama. Seluruh kegiatan Taruna sejak bangun tidur hingga tidur lagi telah diatur dengan rapi. Secara tidak langsung, kampus berasrama memberikan pelajaran 24 jam penuh dengan lingkungan yang unik dan memberikan dorongan kepada Taruna untuk tidak hanya aktif di kelas saja namun juga di luar kelas, seperti ekstrakulikuler dan kegiatan asrama.

Kuliah di kampus ber- asrama tentunya meningkatkan kemandirian anak. Ada atau tidaknya orang tua tentu membawa pengaruh besar terhadap pola hidup si-anak. Kebanyakan akan merasa depresi atau kesepian karena tidak ada orang tua yang bisa dijadikan tempat berkeluh kesah apabila Taruna menghadapi masalah di kampus. Namun disinilah Taruna belajar berusaha untuk menyelesaikan masalahnya sendiri tanpa berlari ke orang tua. Absennya orang tua juga membuat Taruna lebih membuka diri kepada orang lain-teman sekamar, contohnya-sebagai tempat bercerita. Hal ini mengasah kemampuan berinteraksi dan sosialisasi siswa .Karena tinggal di asrama berarti tinggal bersama orang lain, maka tidak dapat dipungkiri bahwa kegiatan kita di luar sekolah juga dilakukan di sekitar orang lain. Secara tidak langsung, Taruna belajar bertoleransi dan berbagi. Latar belakang Taruna yang berasal dari daerah berbeda, budaya, tingkat kecerdasan, dan sikap yang berbeda-beda mampu melatih pola pikir agar berpikir terbuka, menghargai perbedaan, dan mampu memaklumi kebiasaan/budaya orang lain yang berbeda dari kebiasaannya.

Kehidupan diasrama dikenal dengan kepatuhan dan kemandirian yang dapat tercermin dari kemampuannya untuk mandiri tidak hanya secara emosi melainkan juga melainkan juga tingkah laku dan pandangan hidup. Asrama mengajarkan untuk memiliki disiplin dan kesadaran diri dalam melakukan kegiatan apa pun, sehingga nantinya mereka dapat memahami manfaat dari apa yang telah mereka lakukan.

Kemandirian di-asrama meliputi kemandirian dari segi pribadi dan kemandirian darisegi sosial, bergaul dengan teman- temannya secara baik dengan tidak membeda- bedakan antara teman satu dengan teman yang lain, selalu berpikir positif tidak terlalu berburuk sangka, saling bekerja sama dan tolong menolong dalam kebaikan. Selain itu juga terlihat dari aturan- aturan yang dibuat untuk menunjang terciptanya kepatuhan dan kemandirian dalam melaksanakan kehidupannya sehari-hari, walaupun tetap saja semua itu kembali kepada kepribadian masing-masing dan kecerdasan emosi yang dimilikinya.

Budaya disiplin dan mandiri ini juga diharapkan mampu menimbulkan jiwa kepemimpinan. Jiwa kepemimpinan dan kemandirian sangat penting, sebab Taruna dipersiapkan hidupnya dengan 
ilmu yang dimiliki dengan penuh tanggung jawab serta penuh dedikasi tanpa selalu untuk menjadi pemimpin umat di masa yang akan datang, pemimpin yang mampu mengatur bergantung kepada orang lain.

Sayangnya sistem pendidikan asrama ini seperti dua sisi mata uang karena pada sisi lain dapat menghasilkan pribadi

pemberontak yang menabrak segala aturan yangada, antara lain dengan perilaku bullying dan perbuatan negative yang lain. Tinggal dengan orang lain, dengan bermacam karakter dan latar belakang tentunya juga membawa dampak negatif bagi tiap-tiap individu. Bagaimana pun juga,menyatukan sekian banyak kepala di dalam satu lingkungan yang mengharuskan bertemu dari pagi hingga malam bukanlah perkara mudah. Terutama jika terdapat kesenjangan sosial di antara penghuni asrama, misalnya golongan cantik dan tidak begitu cantik. Atau yang paling umum, golongan senior dan junior. Kebanyakan asrama memiliki senioritas yang sangat kuat, yang diwariskan secara turun- temurun dari senior yang sudah lulus ke juniornya yang "naik pangkat"Jabatan penguruspengurus asrama (ketua asrama, bendahara, sekretaris, dan seksiseksi) biasanya diserahkan kepada senior tertinggi sebelum akhirnya mereka mengikuti UN.

Namun terkadang adanya kekuasaan ini justru disalah gunakan oleh oknum-oknum tertentu agar dapat memiliki wewenang atas juniornya. Bukan hanya tentang kedisiplinan namun juga di kehidupan sehari- hari. Oleh karena itu, setiap tingkah laku junior harus dibingkai dengan kesopanan dan patuh terhadap senior. Tentu saja itu termasuk hal baik ketika yang muda dapat menghormati yang lebih tua, tetapi konteks menghormati disini tidak sesuai dengan praktek yang ada di lapangan dimana junior cenderung segan, takut, bahkan traumaterhadap "kakak"-nya sendiri.

\section{Disiplin}

Faktor penting yang dapat mempengaruhi Prestasi Belajar salah satunya adalah Disiplin Belajar. Pengertian disiplin menurut Kamus Besar Bahasa Indonesia adalah ketaatan (kepatuhan) kepada peraturan (tata tertib dan sebagainya). Disiplin merupakan suatu perilaku yang dimiliki seseorang dimana perilaku tersebut menekankan menjunjung nilai moral tinggi Penerapan disiplin yang baik dalam proses pendidikan akan menghasilkan sikap mental, watak dan kepribadian yang kuat. Dosen dituntut harus mampu membelajarkan disiplin diri, belajar membaca,mencintai buku, menghargai waktu, belajar bagaimana cara belajar, mematuhi aturan/tata tertib, dan belajar bagaimana harus berbuat. Semuanya itu akan berhasil apabila dosen juga disiplin dalam melaksanakan tugas dan kewajibannya. Taruna perlu memiliki sikap disiplin dengan melakukan latihan yang memperkuat dirinya sendiri sehingga terbiasa patuh dan mempertinggi daya kendali diri.Menurut Suharsimi (2003 
:114) "disiplin merupakan sesuatu yang berkenaan dengan

pengendalian diri seseorang terhadap bentuk-bentuk aturan di mana aturan tersebut diterapkan oleh orang yang bersangkutan maupun berasal dari luar".

\section{Raw Input}

Raw input adalah calon Taruna yang diperoleh dari hasil seleksi Penerimaan Taruna Baru oleh Kepanitiaan di Lembaga Pendidikan. Dalam seleksi ini Panitia akan mengacu pada ketentuan2 antara lain :
a. Aturan Dikti dan Aturan Dirjen Perhubungan Laut
b. Ketentuan Lembaga dalam hal ini Akpelni
c. Ketentuan Yayasan dalam hal ini Yayasan Wiyata Dharma.

Dari ketentuan tsb diatas
melahirkan persyaratan yang harus dipenuhi Oleh Calon Taruna antara lain 1) sehat jasmani-rohani untuk Pelaut, 2) lulus test akademik, 3) lulus test Psikologi,4) melunasi administrasi dan keuangan. Dari hasil observasi, kepanitiaan ini tidak bisa konsekuen dan konsisten terhadap aturan yang telah ditentukann karena harus membantu atau menolong beberapa orang tertentu yang memiliki Power, sehingga banyak Raw Input yang dibawah standard harus diterima. Raw Input yang kurang baik, akan lebih lama memahami sesuatu yang baru

\section{Metodologi Penelitian dan Hipotesis \\ Penelitian ini adalah Kausal Komparatif (Ex Post Facto)}

dengan metode pendekatan kuantitatif adalah merupakan penelitian yang di arahkan untuk menyelidiki hubungan sebab akibat berdasarkan pengamataan terhadap akibat yang terjadi dan mencari factor yang menjadi penyebab melalui data kuantitatif yang dikumpulkan. Nama ex post facto berasa dari bahasa latin yang artinya "dari sesudah fakta" menujukkan bahwa penelitian itu dilakukan sesudah perbedaanperbedaaan dalam variabel bebas itu terjadi karena perkembangan kejadian itu secara alami. Dalam penelitian ini pendekatan dasarnya adalah dimulai dengan adanya perbedaan dua kelompok dan kemudian mencari faktor yang mungkin menjadi penyebab atau akibat dari perbedaan tersebut. Dalam hal ini ada unsur yang membandingkan antara dua atau lebih variabel. Hubungan kausal adalah hubungan yang bersifat sebab-akibat. Jadi, di sini ada variabel independen (variabel yang mempengaruhi) dan dependen (variabel yang dipengaruhi).

Pengujian hipotesis dalam penelitian ini menggunakan uji $\mathrm{t}$ yaitu untuk menguji pengaruh variabel bebas terhadap variabel terikat, dengan taraf signifikansi $5 \%$. Kriteria uji yang ditetapkan adalah :

a. Sig $t<0.05$, artinya ada pengaruh yang signifikan antara variabel yang diuji, sehingga menolak Ho dan menerima Ha.

b. Sig $\mathrm{t} \geq 0.05$, artinya tidak ada pengaruh yang signifikan antara variabel yang diuji, sehingga menerima Ho dan menolak Ha. 


\section{Hasil Pembahasan}

1. Pada hipotesis 1, disebutkan bahwa bila dosen berkualitas baik, maka hasil didiknya akan berprestasi baik. Berdasarkan hasil penelitian, kualitas dosen tidak berpengaruh pada prestasi belajar Taruna. Artinya walaupun dosen berkualitas baik belum tentu hasil didiknya berprestasi baik (Ha ditolak dan Ho diterima).

2. Pada hipotesis 2, disebutkan bahwa jika metode pembelajarannya berkualitas, maka hasil didiknya akan berprestasi baik. Namun pada penelitian ini, hal itu tidak terbukti. Atau dengan kata lain, walaupun pembelajaran sudah baik, belum tentu hasil didiknya berprestasi baik. (Ha ditolak dan Ho diterima).

3. Pada hipotesis 3, disebutkan bahwa bila Instruktur dan Bintar telah memberikan pendidikan karakter dengan baik, maka hasil didiknya akan baik. Penelitian ini mengungkap bahwa walaupun Instruktur dan Bintar telah memberikan pendidikan karakter dengan baik, belum tentu hasilnya baik. (Ha ditolak dan Ho diterima).

4. Pada hipotesis 4, disebutkan bahwa ada pengaruh kondisi kehidupan Taruna di asrama terhadap prestasi belajar. Pada penelitian ini dihasilkan kesimpulan bahwa kondisi kehidupan Taruna di asrama memiliki pengaruh meskipun nilainya sangat kecil terhadap prestasi belajar mereka (Ha diterima dan Ho ditolak).

5. Pada hipotesis 5, disebutkan bahwa ada pengaruh kedisiplinan terhadap prestasi belajar. Penelitian ini menunjukkan bahwa pembinaan kedisiplinan atau yang disebut dengan Character Building memiliki pengaruh terhadap prestasi belajar Taruna meskipun tidak signifikan (Ha diterima dan Ho ditolak).

6. Pada hipotesis 6, disebutkan bahwa bila raw input baik, maka prestasi belajar akan baik. Penelitian ini sangat mendukung hipotesis ini dengan nilai signifikansi yang memenuhi kriteria. Sehingga dapat dikatakan bahwa raw input yang baik pasti mempengaruhi nilai prestasi belajar (Ha diterima dan $\mathrm{Ho}$ ditolak).

\section{E. Kesimpulan dan Rekomendasi}

1. Sudah sepatutnya jika dirumuskan hipotesis bahwa kualitas dosen memberikan pengaruh yang signifikan pada prestasi belajar Taruna. Namun penelitian ini menunjukkan hal yang berbeda dan harus mendapat perhatian. Menjadi pertanyaan besar bagi kita sekalian jika didapati kenyataan bahwa dosen ternyata tidak mempengaruhi kualitas anak didiknya, bahkan penelitian ini menunjukkan adanya pengaruh negatif dari dosen. Jika kita mencermati tabel 4.3 maka dapat kita ketahui bahwa untuk manajemen kinerja dosen skornya adalah 3,76 (skala 5) dan untuk kompetensi dosen skornya adalah 4,11. Sepintas ini cukup tinggi, tetapi jika kita lihat nilai minimalnya yang 
hanya 2,77 dan 1,81, bahkan ada indikator yang memiliki nilai minimal 1,36 yaitu Kompetensi Pedagogik, maka dapat disimpulkan bahwa beberapa dosen belum memiliki manajemen kinerja dan kompetensi yang cukup memadai untuk mendukung peningkatan prestasi belajar. Hal yang patut diduga terkait hal ini adalah banyaknya beban mengajar dosen sehingga perhatian kepada Taruna menjadi berkurang. Dosen seolah-olah hanya mengejar penyelesaian tugas sesuai jadwal mengajar tanpa memperhatikan dengan saksama kualitas pencapaian pemahaman oleh Taruna, sehingga pada saat ujian akhir nilai Taruna tidak mencapai sebagaimana target yang diharapkan. Tim peneliti merekomendasikan adanya evaluasi lebih mendalam pada para dosen dan pembenahan seperti pembatasan beban mengajar dan peningkatan kompetensi.

2. Hal kedua yang juga mencengangkan adalah kenyataan bahwa proses pembelajaran yang ada belum memberikan dukungan pada pencapaian hasil belajar yang memuaskan. Jika dilihat dari Tabel 4.4, didapati bahwa nilai dimensi proses pendidikan adalah 3,50, paling kecil dibandingkan dimensi input $(3,57)$ dan output $(3,59)$. Penelitian ini menghasilkan temuan fakta yang menyatakan bahwa kualitas pembelajaran belum memberikan pengaruh yang signifikan terhadap peraihan prestasi belajar

Taruna. Tentu hal ini ada keterkaitan dengan pembahasan pada butir 1 di atas dimana dosen sebagai pelaku proses pembelajaran tersebut. Jika dicermati lebih jauh, kompetensi dosen termasuk salah satu indikator dalam dimensi proses ini selain indikator pengelolaan lembaga dengan baik berdasarkan standar Nasional dan Internasional, staf akademik yang memberikan kepuasan layanan, proses monitoring berkelanjutan selama proses pembelajaran, dan evaluasi guna peningkatan kualitas pendidikan. Tim peneliti merekomendasikan adanya evaluasi terhadap proses pembelajaran secara menyeluruh dan perlu dicoba langkah-langkah untuk meningkatkan kualitas pembelajaran sehingga Taruna merasa nyaman dalam belajar dan semakin semangat untuk meraih nilai tertinggi dalam belajarnya.

3. Selain proses pendidikan secara akademis, di Akpelni terdapat pendidikan karakter yang dilaksanakan oleh Instruktur dan Bintar. Tentunya kita semua berharap bahwa Instruktur/ Bintar dapat ikut mendukung peningkatan prestasi belajar Taruna. Namun pada kenyataannya penelitian ini menunjukkan bahwa Instruktur/ Bintar tidak memberikan pengaruh yang positif dan signifikan terhadap prestasi belajar Taruna. Perlu diketahui terlebih dahulu bahwa kuesioner sebanyak 16 
responden, keseluruhannya adalah Bintar dan tidak ada Instruktur yang ikut mengisi kuesioner tersebut. Jika dilihat dari skor rataan/ nilai minimal, maka pada variabel ini kita dapati indikator kompensasi menduduki urutan terendah $(2,20 / 1,56) \quad$ setelah iklim organisasi $(3,70 / 3,04)$ dan kepuasan Instruktur/ Bintar $(3,87 / 3,13)$. Di satu sisi para Bintar merasakan bahwa kompensasi yang diterima masih sangat kecil, sementara di sisi lain mereka cukup puas dengan pekerjaan mereka dan iklim organisasi yang adapun cukup baik. Hal ini mungkin mengakibatkan Bintar harus melakukan pekerjaan lain juga untuk mencukupi kebutuhan hidupnya sehingga tidak fokus dalam melaksanakan tugasnya. Kemungkinan lain yang perlu diteliti lebih lanjut yaitu Taruna menempatkan diri sebagai junior dari para Bintar sehingga ada perasaan takut atau tertekan selama menjalani proses pembelajaran, dan akibatnya prestasi belajarpun menurun.

4. Suasana kehidupan di Asrama (saat ini disebut Gedung Pembinaan Karakter), menurut penelitian ini, memiliki pengaruh terhadap prestasi belajar Taruna, meskipun nilainya sangat kecil dan tidak signifikan. Sayangnya dari 28 indikator yang diajukan, hanya 14 yang dinyatakan valid. Pernyataan yang valid tersebut antara lain terkait dengan adanya pembinaan karakter yang kekeluargaan dan agamis serta adanya kontrol secara rutin dari dosen, intruktur, dan Bintar. Sementara pernyataan yang tidak valid adalah hal-hal yang dirasa negatif seperti penyesalan kuliah di Akpelni, pengambilan keputusan kuliah hanya untuk menyenangkan orang tua, dan suasana asrama yang kadang kurang menyenangkan. Tim merekomendasikan bahwa sudah seharusnya suasana kehidupan di asrama terus diperbaiki sehingga bisa meningkatkan perannya yang saat ini baru $0,5 \%$ dalam mendukung prestasi belajar Taruna.

5. Kedisiplinan sering disebut sebagai nafas taruna sehingga seharusnya disiplin memberikan efek positif terhadap prestasi belajar. Penelitian ini mengungkapkan bahwa disiplin yang merupakan bagian dari Character Building, memberikan pengaruh terhadap prestasi belajar, meskipun juuga tergolong kecil yaitu sebesar $\quad 1,5 \%$. Prioritas pembenahan adalah dimensi produktif yang memiliki skor paling rendah sebagaimana pada Tabel 4.7. yaitu sebesar 2,97. Dimensi produktif di dalamnya juga mengandung indikator kegiatan yang mendukung pembelajaran agar dilaksanakan dengan baik dan juga efisiensi pelaksanaan kegiatan di luar pembelajaran. Dengan pengaturan yang lebih baik, bukan tidak mungkin kondisi kehidupan yang lebih baik di asrama juga meningkatkan prestasi belajar Taruna. 
6. Satu-satunya variabel bebas yang dinyatakan mendukung variabel terikat secara positif dan signifikan adalah raw input. Bahkan jika dilepaskan dari variabel yang lain, maka pengaruhnya cukup besar yaitu sekitar $65,4 \%$. Hal ini sangat mudah dipahami yaitu ketika sumber masukannya sudah baik, maka hasil keluarannya juga baik, apalagi jika ditambah proses yang baik pula. Raw input penelitian ini adalah dimensi fisiologis dan psikologis Taruna, motivasi internal maupun eksternal, dan rata-rata nilai rapor selama di SMA, rata-rata nilai UAS dan UN. Oleh karenanya seleksi yang ketat harus diterapkan dalam menjaring calon taruna di masa mendatang, sehingga upaya mendapatkan Indeks
Prestasi Semester maupun Indeks Prestasi Komulatif yang tinggi akan lebih mudah tercapai.

\section{DAFTAR PUSTAKA}

Ghozali, Imam. 2013, Aplikasi Analisis Multivariate dengan Program IBM SPSS 21, edisi 7, Semarang;BP Universitas Diponegoro

Huijbers, Theo. 1995, Filsafat Hukum, Yogyakarta, Kanisius

Koesoema A., Doni. 2007, Pendidikan Karakter, jakarta : Grasindo

Sugiyono. 2010. Metode Penelitian Administrasi. Bandung : CVC. Alfabeta

Tjiptono, Fandy. 1997. PrinsipPrinsip Total Quality Service. Yogyakarta : Andi 